\title{
Combined immunodeficiency due to partial RAG1 deficiency
}

INSERM

\section{Source}

INSERM. (1999). Orphanet: an online rare disease and orphan drug data base. Combined immunodeficiency due to partial RAG1 deficiency. ORPHA:231154

Combined immunodeficiency due to partial RAG1 deficiency is a form of combined T and B cell immunodeficiency (CID; see this term) characterized by severe and persistent cytomegalovirus (CMV) infection and autoimmune cytopenia. 